\title{
Rethinking Scholastic Communities in Latin Europe: Competition and Theological Method in the Twelfth Century
}

\author{
Constant J. Mews*
}

This paper explores the role of competition between masters and their communities in shaping the dynamism of theological debate in twelfth-century Europe. Whereas scholastic debate in the thirteenth century was heavily influenced by the structures and curriculum of the University of Paris, this was not the case in the twelfth century. While there were celebrated confrontations between individual monks and schoolmen (such as St Anselm against Roscelin of Compiègne, and Bernard of Clairvaux against Peter Abelard), it is inadequate to interpret these episodes in terms of simple opposition between monastic and scholastic theological traditions. Rather, we see the evolution of a range of educational communities, of monks, of regular canons, and of secular clergy, each with their own interpretation of Christian teaching, and with their own attitudes to the use of reason and the learning of classical antiquity. After 1150, there was an increasing tendency to professionalization in the teaching of theology, epitomized by the growing influence of Peter Lombard's Sentences, but there was no consensus about the extent to which it should also engage in philosophical reflection. There was also competition between the cathedral school at Notre-Dame and the canons of Saint-Victor, who preferred to emphasize the role of experience in the spiritual life. The case of Richard of Saint-Victor's writing on the Trinity shows how he sought to combine an experiential dimension to religious insight, with presentation of Christian teaching in terms of reason, rather like St Anselm, rather than through debating patristic authority, as followed by disciples of Peter Lombard. The label of scholasticism should not conceal the enduring diversity of approaches adopted by different communities.

Keywords: twelfth century; Parisian schools; monasticism; canons regular; theology; exegesis; Cathedral of Notre-Dame, Paris

* Correspondence details: Constant J. Mews, Centre for Religious Studies, School of Philosophical, Historical and International Studies (SOPHIS), Monash University, Victoria 3800, Australia; email: Constant.Mews@monash.edu. 


\section{Introduction}

In 1974, George Makdisi articulated a widely held view of scholasticism in the Latin West when he defined it in terms of the Sic et non method, dialectic, and disputation, and as epitomized »in its finished and most perfect form« in the Summa theologiae of Thomas Aquinas (1225-1279). He argued that similar concerns could be identified in great thinkers of the Islamic tradition. ${ }^{1}$ This image of scholasticism as a fundamentally stable system, involving the reconciliation of faith and reason, was certainly promoted by Pope Leo XIII in his 1879 encyclical, Aeterni patris, mandating the authority of Aquinas in teaching theology. It inspired a massive outpouring of scholarship, embodied, for example, in the work of Martin Grabmann and his many disciples. ${ }^{2}$ Yet if we are to seek cross-cultural parallels for Latin scholasticism, it may be more helpful to look at Europe in the twelfth rather than the thirteenth century, prior to the establishment of a formal curriculum for the University of Paris in $1215 .{ }^{3}$ At that time there was no dominant institution able to define the approved method of pursuing intellectual inquiry. While twelfth-century theology can be approached in terms of the history of ideas, it also deserves to be studied as generated by competition between masters and their various schools or communities, each with their own way of responding to voices and texts emanating from outside the Latin West. ${ }^{4}$

A common narrative traditionally used to explain the development of theology in the twelfth and thirteenth centuries is that of a continuing tension between monastic and scholastic perspectives. The idea that monasticism developed its own distinct theology, based around contemplative study of scripture and opposed to analytic inquiry into doctrine, was first developed in the 1960 s and 1970 s by the great monastic scholar, Jean Leclercq. He identified the experiential and contemplative focus of what he called monastic theology, embodied by Bernard of Clairvaux (1090-1153) as in opposition to the analytic, disputatious character of scholasticism, as personified by Peter Abelard (1079-1042). ${ }^{5}$ As Quinto observed, the term "scholastic" has long been shaped by a rhetorical implication that it was less than fully spiritual. ${ }^{6}$ Marcia Colish has written eloquently about the need to remap the complexity of scholastic theology, going beyond new-Thomist perspectives. She has done much, in particular, to rehabilitate the contribution of Peter Lombard to the development of systematic theology. ${ }^{7}$ Yet the notion of monasticism and scholasticism as competing perspectives still

1 Makdisi, Scholastic method, 642; Makdisi develops his arguments about core elements of common ground in a series of publications, Rise of Colleges (1981), Rise of Humanism (1990), and in his overview lecture, Scholasticism and humanism. His arguments are reviewed by Madigan, Islam's true scholasticism.

2 For an overview of Thomism until 1974, see Colish, St Thomas Aquinas, and the papers in Brezik, One Hundred Years and Gangl, Franz Ehrle; for a more critical view, see Ventresca, "Plague«. The classic expositions of the evolution of scholasticism, and of scholastic theology have been in German and French, notably Grabmann, Geschichte der scholastischen Methode, Pieper, Scholasticism: Personalities and Problems, and (for the twelfth century), Ghellinck, Mouvement théologique and Landgraf, Introduction à l'histoire. More recent are the surveys of Leinsle, Introduction to Scholastic Theology and of D'Onofrio, History of Theology 2 (published in English without the detailed footnotes in the original Italian edition).

3 Chartularium Universitatis Parisiensis no. 20, 1, ed. Denifle, 78-80.

4 For extensive discussion of the complexity of these networks, see Steckel, Networks of learning and Mews, Communities of learning.

5 Leclercq, Love of Learning; the distinction is defended by Gastaldelli, Teologia monastica.

6 Quinto, Scholastica.

7 Relevant studies by Colish include: Systematic theology (1988), Authority and interpretation (2004), and Remapping scholasticism (2000), reprinted in a volume of her collected papers, Studies in Scholasticism (2006). 
surfaces in historiography. In a stimulating study of the profound changes in educational practice between the twelfth and thirteenth centuries, Ian Wei finely documents the transition from the early twelfth century, marked by clearly distinct personalities, to the institutionalization of learning evident in the thirteenth century. He argues that a theological elite gradually eliminated what he identifies as "the monastic critique« of learning, evident in the previous century. ${ }^{8}$ The problem with this monastic/scholastic binary is that it does not easily accommodate the diversity of theological perspectives and methods within the twelfth century, or explain the diffusion of many scholastic texts within a monastic milieu. ${ }^{9}$ In particular, it has difficulty in accommodating the achievement of Victorine thinkers, most famously Hugh of Saint-Victor, except as figures who combined monastic and scholastic perspectives. Another way of mapping scholasticism may be to identify the range of communities involved in interpreting their canonical texts and in explaining their key teachings. Both masters and their communities varied in the extent to which they sought to engage with philosophical learning and in the method of enquiry they pursued. Over the course of the twelfth century, traditional Benedictine monasticism lost much (although not all) of its traditional dominance in both education and society, as new religious communities, in particular following the Augustinian Rule, started to emerge alongside the expansion of schools attached to cathedrals and major urban churches. To define Latin scholasticism, at least within the domain of theology, in terms of a single method that involved both reason and authority does not do full justice to the range of ways different communities sought to interpret the scriptures and to summarize their teaching.

\section{(1) The Early Scholastic Period 1090-1150: competing masters}

An early episode of a monk arguing with a schoolman is provided by Anselm of Bec (10331108), subsequently appointed archbishop of Canterbury, when he accused Roscelin of Compiègne (c. 1050-c. 1125) of making heretical claims about the Trinity immediately prior to his trial at the Council of Soissons (c. 1090). Anselm reported in his De incarnatione Verbi that Roscelin justified the need for a fresh account of the doctrine of the Trinity by reference to the teaching of both Jews and Muslims, or pagani as he called the latter: "The pagans defend their Law, the Jews defend their Law, therefore we Christians must defend our faith. $\aleph^{10}$ Anselm was not opposed to such a goal, but rather sought to improve on the explanation offered by Roscelin, whom he dismissed as "one of those modern dialecticians who understand nothing to exist other than what they can grasp by their imagination. ${ }^{11}$ Roscelin argued that

8 Wei, Twelfth-century schools, 78, and Intellectual Culture, 72-78.

9 On early copies of Peter Lombard's Sentences and Commentary on the Pauline Epistles at the monastic library of Admont, see Mews, Scholastic theology, 228.

10 Anselm of Canterbury, De incarnatione Verbi 2, in Anselmi Opera Omnia 2.2, ed. Schmitt, 2:10: „Pagani defendunt legem suam, Iudaei defendunt legem suam. Ergo et nos Christiani debemus defendere fidem nostram.«

11 Anselm, De Incarnatione Verbi (prior recensio), c. 10 ed. Schmitt 1:289 and c. 4, ed. Schmitt, 2:17. 
the three persons of the Trinity had to be defined as separate things (res), if one was to avoid saying that God the Father himself became incarnate in the Son, an argument that reflected his applying traditional Augustinian semantic theory that any utterance could be used as the sign of a thing (res) for each of the three persons. ${ }^{12}$ In searching out arguments from reason rather than authority, Anselm was developing a scholastic technique very different from the patristic focus of Lanfranc of Bec (c. 1010-1089) in his polemic against Berengar of Tours (c. 999-1088) about the eucharist. ${ }^{13}$ There was also a political context to his accusations against Roscelin. The monk John, who had reported Roscelin's heresies to Anselm, was then defending Fulco, another Bec monk, newly installed as bishop of Beauvais, from hostile clerics in the city. Roscelin seems to have been based at St Vaast, a collegiate church in Beauvais, established by a previous bishop, Guy, its bishop 1063-1085, until he was ousted from the diocese by hostile forces. ${ }^{14}$ The theological dispute was between rival teachers and their communities, not between monastic and scholastic traditions in general.

In a subsequent treatise, the Cur Deus homo, written in the form of a philosophical dialogue, Anselm has his disciple Boso exclaim that in demonstrating the necessity of a Godman by reason alone, he had found a way to respond to the arguments "of both Jews and pagans $\ll .{ }^{15}$ Anselm was here invoking Roscelin's argument about the need to respond to Jews and Muslims to justify formulating what he considered a more rationally acceptable theory of redemption than often taken for granted in preaching: that humanity needed to be rescued from having fallen under the devil's yoke. Anselm's explanation of the incarnation helped Gilbert Crispin (c. 1055-1117), prior of Westminster Abbey, to compose a dialogue between a Christian and a Jew, whom he describes in relatively friendly terms as having been educated in the rabbinical schools of the Rhineland. ${ }^{16}$ Anselm's writings circulated relatively widely in a monastic milieu in England, Normandy and southern Germany, places where monks were often engaged in pastoral care. By contrast, Anselm's writings would not be cited as authoritative in the Parisian schools until the early thirteenth century.

The fluidity of scholastic culture in the early twelfth century is nowhere more evident than in Abelard's Historia calamitatum, written in the early 1130s. In much of his account, he devotes more attention to critics within the schools than to those within monastic circles. ${ }^{17}$ Through the careful political analysis of its narrative by Robert-Henri Bautier, we have a much better understanding of the political context to debates about dialectic and scripture in which the young Abelard was involved. ${ }^{18}$ Soon after Abelard came to Paris in c. 1100 to

12 Mews, Bruno and Roscelin, 142-143.

13 On Lanfranc's method, see Cowdrey, Lanfranc and on the debate with Berengar, Chadwick, Symbol and reality.

14 Roscelin's heresy was reported to Anselm of Bec by John of Telese, then adviser to Fulco, Bishop of Beauvais (10881095) in Fulco's adviser, Ep. 128-129 (Anselmi Opera Omnia, 3: 270-271), immediately following an exchange with Pope Urban II about difficulties with Fulco in Ep. 125-127 (3. 267-269). On his identity with Roscelin, who established St Vaast in 1072 alongside Nevelo of Compiègne, see Mews, See of Beauvais. Guibert of Nogent speaks about Guido's career in Autobiographie 1. 14, ed. Labande, 100.

15 Cur Deus homo, 2.22, in Anselmi Opera Omnia, ed. Schmitt 2: 133.

16 Gilbert Crispin, Disputatio Iudei et Christiani. Many translations of eleventh-century Jewish responsa, often from Rhineland rabbis, are collected by Agus, Urban Civilization.

17 The major monastic critic he mentions is a prominent reformer of monastic life, certainly Bernard of Clairvaux, Abelard, Letter 1.58, ed. Luscombe, 90.

18 Abelard, Letter 1 (Historia calamitatum), ed. Luscombe, 2-121; Bautier, Paris au temps d'Abélard, 53-62. 
study under William of Champeaux at the cathedral school of Notre-Dame, having spent at least five years or so under Roscelin at Loches and then Tours, he attached himself politically to William's great rival in the cathedral, the politically influential Stephen of Garlande, whose brothers helped him establish a school at Melun, and then Corbeil (1104-1107). ${ }^{19}$ After a period away from Paris (1107-1011), while William of Champeaux was asserting himself as a newly appointed archdeacon of Paris, Abelard returned to Paris to re-establish himself as a teacher. At Easter 1111, William resigned from the cathedral to establish a new community around a disused chapel of Saint-Victor on the left bank of the Seine. Abelard in the meantime, supported by Stephen of Garlande, established his school under the protection of the abbey of Sainte-Geneviève. ${ }^{20}$ Whereas Sainte-Geneviève was an abbey of secular canons, Saint-Victor was a community of canons regular, pursuing a quasi-monastic life without being formally enclosed in the manner of monks. At Saint-Victor, a German student reports that William, "the most accomplished instructor in every branch of learning, taught a full range of divine and human sciences."William established a precedent that Abelard would himself seek to emulate in his own teaching. William believed in giving equal attention to grammar, dialectic and rhetoric, paying particular attention to Boethius as his intellectual guide. ${ }^{21}$

In teaching secular disciplines alongside "divine science«, William was departing from the practice of his own teacher, Anselm of Laon, who never combined philosophical and scriptural authorities to any significant degree in his teaching. Abelard mocked Anselm's way of teaching as based on authorities, but lacking in substance. ${ }^{22}$ His harsh words should not detract from his awareness of Anselm's achievement in collecting and making available patristic authorities, both within commentaries on specific books of the Bible and in exposition of Christian teachings. ${ }^{23}$ Anselm's commentary on John's Gospel is heavily dependent on patristic authority, above all that of Augustine. When he explains words of Hebrew origin, he generally relies on patristic summaries of their meaning. ${ }^{24}$ In glossing John 10:1, Anselm adds within passages taken from Alcuin on Augustine a sentence of his own about neither Jews nor pagans as able to enter Christ's kingdom: »Through this door, Jews proudly against Jesus do not enter, pagans do not enter, even though they may seem to be just among men and observe equity, but this is of no use to them. ${ }^{25}$ The added sentence suggests a deliberate riposte to those (like Abelard), who emphasized in their writing the moral integrity of Jews and pagans.

19 Abelard, Letter 1.4-5, ed. Luscombe, 6.

20 On the letter of a German student of William, reporting that he resigned from Notre-Dame at Easter 1111, (not 1108 as often claimed), see n. 55 and Mews, William of Champeaux, 90-91.

21 The letter of a German student comparing Willian of Champeaux to Manegold of Lautenbach is preserved in the Codex Udalrici, ed. Jaffé, no. 160, 286.

22 Peter Abelard, Letter 1.10, ed. Luscombe, 16-17.

23 The most thorough study of Anselm of Laon is that of Giraud, Per verba magistri; see also Smith, Glossa ordinaria and Andrée, Anselm of Laon unveiled.

24 Anselm of Laon, Glossae super Iohannem, 2:14, 4:25, 5:2, 6:1, 12:13, 13:1, 19:19, ed. Andrée, 45, 72, 79, 99, 218, 232, 327.

25 Anselm of Laon, Glossae super Iohannem, ed. Andrée 10:1 (185): "Per hanc ianuam non intrant iudei aduersus Iesum superbientes, non intrant pagani, quamuis uideantur iusti inter homines et aequitatis obseruatores, sed nichil ei prodest.« 
Abelard's students seem to have had a deeper familiarity with dialectic and pagan authors than those who admired Anselm of Laon. Abelard's account of how he was able to respond to the demands of Alberic of Reims, subsequently archbishop of Bourges (1136-1141), that he adduce patristic authority for his argument about the Trinity highlights how he was forced to engage with the Laon method of engaging with Church Fathers, so different from that of Anselm of Bec. ${ }^{26}$ In the earliest version of his treatise on the Trinity (the Theologia "Summi boni«), Abelard buttressed his argument by only a limited number of patristic authorities. After the 1121 Council of Soissons, however, he started to pay much more attention to the Church Fathers, both in the Theologia christiana and in his Sic et non. ${ }^{27}$ He also expected them to be fully familiar with those philosophical authorities whom he saw as exemplifying St Paul's teaching in Romans 1:19-20 about the Invisibilia Dei being manifested through creation and potentially accessible to all. ${ }^{28}$ Whereas Roscelin had identified the words "Father", "Son" and "Holy Spirit" as referring to specific things, Abelard explained the three persons as names given to the power, wisdom and benignity of God. The controversial character of his claims rested on the way he seemed to downplay divine omnipotence in relation to its wisdom and benignity. Abelard's explanations were not easily accessible to those unfamiliar with his philosophy of language and thus were never widely diffused in the manuscript tradition, as compared to the more straightforward summaries of the teachings of Anselm of Laon and William of Champeaux.

Even more influential as an educational community was that which developed around Hugh of Saint-Victor. In his Didascalicon (now thought to be written c. 1121, rather than c. 1125 as traditionally thought), Hugh articulates a vision of learning in which he considers (in its first three books) all the liberal arts, including dialectic or the art of distinguishing truth from falsehood, within the framework of wisdom. In the last three books, he considers the scriptures and the process they require of reading, understanding, prayer and contemplation. ${ }^{29} \mathrm{He}$ offers polemic, not against pagan authors as such, but only against those teachers (undoubtedly referring to Peter Abelard) who seemed contemptuous of other teachers of divinity: "They turn up their nose and purse their lips against teachers of divinity, and do not understand that they cause offence to God, whose simple words, beautiful in expression, they preach as if tasteless, with distorted sense. ${ }^{30}$ Hugh's treatise was an attempt to maintain a contemplative framework for a discipline that was being transformed by Abelard's love of disputation and questioning of traditional authorities.

26 Abelard, Letter 1.39, ed. Luscombe, 60-62.

27 Abelard's growing citation of philosophical and patristic texts is evident from the Index scriptorum in the edition of the Theologia "Summi boni« and Theologia "Scholarium", in CCCM 13, 571-602.

28 This key Pauline passage was frequently cited by Abelard in every version of the Theologia, CCCM $13,566$.

29 Didascalicon 5.9, ed. Buttimer, 109; on the date of the Didascalicon, see Poirel, Tene fontem, 307-311.

30 Didascalicon 3.13, ed. Buttimer, 64: „Corrugant nasum et ualgium torquent in lectores diuinitatis, et non intelligunt quod Deo iniuriam faciunt, cuius uerba pulchro quidem uocabulo simplicia, sed sensu prauo insipida predicant.« 
Hugh of Saint-Victor differed from Anselm of Laon in the extent to which he integrated explanations of Hebrew terms in the Pentateuch, which he recognizes that Jews call the Torah. ${ }^{31}$ His frequent use of phrases like secundum Hebraeos and apud Hebraeos, alludes not just to opinions derived from Jerome, but from explanations derived from disciples of Rashi of Troyes (1040-1105), who had himself pioneered emphasis on the peshat, or historical sense, of the Hebrew scriptures. ${ }^{32}$ Mordecai Cohen has argued that the innovative aspect of Rashi's exegesis could itself have been inspired by the originality of Bruno of Rheims (c. 1030-1101), but the very limited diffusion of Bruno's commentary on the Psalms, makes this possibility hard to believe. ${ }^{33}$ While Anselm of Laon might have prompted collecting patristic interpretations of scripture out of a desire to compete with Rashi's initiative in commenting on the Hebrew Bible, he never refers to Hebraei in the commentaries circulated under his name in the manner of Hugh of Saint-Victor. Hugh transformed exegetical method by including, to a limited degree, the opinions of a disciple of Rashi, presumably from the Jewish community in the central area of the Île-de-la-Cité, between the royal palace and the cathedral. While Jewish communities participated in an extensive network of responsa from leading rabbis, active in both Champagne and the Rhineland, it was only very occasionally that Christian scholars thought fit to benefit from their expertise, such as when Cistercian monks sought advice on the text of the Books of Kings. ${ }^{34}$ Hugh demonstrates a line of interest in the historical foundation of scripture that would be much extended in the 1140 s by his disciple, Andrew of Saint-Victor, whose commentaries on the Old Testament would never gain the wide readership experienced by those of Hugh. ${ }^{35}$ As Rebecca Moore argues, this willingness to acknowledge Jewish interpretations would not be extended to a number of subsequent scriptural commentaries produced at Saint-Victor, subsequently assigned to Hugh but of doubtful authenticity. ${ }^{36}$

This fascination with Jewish exegesis would also be picked up by Peter Abelard in response to one of Heloise's Problemata about scripture. ${ }^{37}$ Scholastic discussion was often generated by discussions outside the schools. The sympathetic portrayal of a Jew in dialogue with a philosopher in his Collationes may itself have been inspired by awareness of Rabbenu Tam (c. 1100-1171), a distinguished Tosafist and grandson of Rashi, who lived at Ramerupt in the region of Troyes, who pursued a rationalizing approach to resolving discords within the Torah. The fact that Rabbenu Tam responded to a question about Enoch put to him by Henry the Liberal, Count of Champagne, suggests such Jewish-Christian exchanges as Abelard presented in literary form may have had some foundation in experience. On the other hand, there is no evidence that Abelard ever engaged in dialogue with any educated Muslim, even if he fondly imagined that there might be more tolerance in Muslim Spain than in Latin Europe. ${ }^{38}$ Victor.

36 Moore, Jews and Christians, 95-112.

37 Heloise, Problemata Heloissae 36, col. 718A: „Ita Hebraeum quemdam audivi exponentem: Nummus argenteus... redimebat se a sacerdote.« On this passage, see Mews and Perry, Jewish Biblical exegesis.

38 Abelard, Letter 1.59 , ed. Luscombe, 92. 
When Abelard resumed teaching in Paris in the 1130s, there was no single corporate structure regulating the schools. ${ }^{39}$ There was also no consistency of method between different teachers. Hugh of Saint-Victor put equal weight on the historical, allegorical and tropological or moral senses of scripture, without privileging the authority of the Fathers in the manner of disciples of Anselm of Laon. By contrast, Abelard expected his students to come to the study of scripture having already been exposed to his teaching on dialectic, while he also engaged in critical examination of patristic authorities. Abelard's Sententie Parisienses provides one record among many of his oral teaching, structured around discussion of God (theologia) and his benefits, above all the supreme love (summa dilectio) manifest in Christ, the sacraments, and caritas itself. ${ }^{40}$ This organization contrasted with that of Hugh of Saint-Victor's De sacramentis, structured around themes of the creation and restoration of the world.$^{41}$ While Abelard delivered his overview of Christian teaching in lectures, he preferred to develop his ideas within individual treatises that were preserved in select monastic libraries, but not in the wide numbers accorded to the writings of Hugh of Saint-Victor.

The fact that Bernard of Clairvaux was asked to lead a campaign against Abelard that culminated in accusations of heresy being made at the Council of Sens in May 1141 does not mean that the conflict was between monastic and scholastic theologies. In his Letter 190, addressed to Pope Innocent II, Bernard focused not on Abelard's use of reason, but on those passages in which he seemed to undermine divine omnipotence and Christ's redeeming work. ${ }^{42}$ As a former protégé of William of Champeaux (by whom he had been consecrated abbot of Clairvaux in 1115), Bernard was voicing the views of those masters who considered that Abelard departed too radically from traditional Augustinian assumptions about human sinfulness. Bernard was particularly alarmed by the potentially destabilizing influence of $\mathrm{Ab}$ elard's disciple, Arnold of Brescia, whom he feared was using Abelard's teaching to question the authority of Pope Innocent II within the city of Rome. ${ }^{43}$ Arnold eventually returned to Rome during the papacy (1143/1144) of Celestine II, who as Guy of Castello had been an admirer of Abelard, but who would survive only five months in that position - "poisoned by his own « according to a Bolognese chronicler. ${ }^{44}$ The list of books bequeathed by Guy at his death included important manuscripts of Abelard's Theologia christiana and Sic et non, showing Guy to be sympathetic to scholastic educational culture..$^{45}$ Bernard was distressed by the extent of Abelard's influence in the curia. At the same time, he supported other schoolmen, like the young Peter Lombard, for whom he wrote a letter of introduction to Saint-Victor, after Peter had studied under Alberic of Rheims. ${ }^{46}$

39 John of Salisbury, Metalogicon 2.10, ed. Hall, 70-73.

40 Sententie Parisienses, ed. Landgraf, 29.

41 Hugh of Saint-Victor, De sacramentis, Praef., cols. 173-174.

42 Bernard of Clairvaux, Letter 190, Sancti Bernardi Opera, ed. Leclercq et al., 8: 17-40.

43 Bernard touches on the closeness of Arnold to Abelard in Letter 189.3, ed. Leclercq et al., 8:14; John of Salisbury, Historia pontificalis 31, ed. Chibnall, 63-65; on the political situation in which Arnold was involved, see Mews, Council of Sens.

44 John of Salisbury, Historia pontificalis 31, ed. Chibnall, 63-65; Corpus chronicorum Bononiensium, ed. Sorbelli et al., 2: 22 (Cronaca A): "Anno Christi MCXL4 [sic] Celestinus secundus sedit mensibus v, diebus 13. Hic natione Tuschus de castro Felicitatis sepultus est in Laterano, ut dicitur, venenatus a suis. « This chronicler reports the restoration of the Senate in 1147, with pride rather than hostility (2:22): »Huius tempore Senatus renovatur in alma urbe Romana."

45 Wilmart, Livres légués.

46 Bernard of Clairvaux, Ep. 410, ed. Leclercq et al., 8: 391. 
The competitive character of scholastic communities in the mid-twelfth century is also evident from the account offered by John of Salisbury in the Metalogicon of his education during the years 1136-1148. He identifies a number of masters under whom he certainly studied in Paris, but never explicitly explains where he learned about the humanistic pedagogical traditions established by Bernard of Chartres and his various disciples, including his brother Thierry, William of Conches, and Gilbert de la Porrée, subsequently bishop of Poitiers. ${ }^{47}$ While Richard Southern proposed that John pursued these studies at Paris rather than at Chartres, there can be no doubting the importance of the latter's cathedral library, which included many volumes bequeathed by Thierry of Chartres. ${ }^{48}$ Within a philosophical dialogue about the teaching of Gilbert of Poitiers, Everard of Ypres attributes to his friend Ratius a comment that when he listened to Gilbert at Chartres, there were four students in the class, as distinct from three hundred in the lecture hall at Paris (sometime before 1141/1142). ${ }^{49}$ The comment highlights the elite character of education at the cathedral school of Chartres, as compared to the situation in Paris, where there was a much greater concentration of masters.

Of particular significance for theology was the emphasis placed at Chartres on the Opuscula sacra of Boethius, with its emphasis on presenting core Christian teachings about the Trinity and Christology through philosophical reasoning, rather than through the authority of the Church Fathers. While Thierry of Chartres produced commentaries on the treatise of Boethius on the Trinity that privileged mathematics as a way of speaking about divine harmony, Gilbert of Poitiers (c. 1085-1154), chancellor of its cathedral between 1126 and 1142, composed a much more widely copied philosophical commentary on the work. ${ }^{50}$ Gilbert skilfully combined Platonic and Aristotelian traditions by applying the distinction between that which is (id quod est) and that by which everything exists (id quo est) to both philosophical reality and the Trinity. His reflections were not intended for a mass audience such as could be found in Paris. Yet the fact that his commentaries were preserved in monastic libraries, including of the Cistercians, confirms the inadequacy of assuming that there was ever a single theological perspective pursued in a monastic environment. In his Historia pontificalis, John of Salisbury wryly documents the inadequacy of the attempts of Bernard of Clairvaux and his supporters to accuse Gilbert of Poitiers of heresy. ${ }^{51}$ John empathized with Gilbert's more philosophically educated perspective on scripture and Christian faith, so different from that of Bernard of Clairvaux. Bernard's devotees emphasized the superiority of religious experience, mediated through scripture (above all the Song of Songs), against those they caricatured as arid scholastic intellectuals, who had lost touch with the true depths of divine revelation.

47 John of Salisbury describes his studies under William of Conches and other masters working in the tradition of Bernard of Chartres in Metalogicon 1.24, ed. Hall, 51-55.

48 Southern, Humanism and the school; Giacone, Masters, books and the library; see also Giraud and Mews, John of Salisbury.

49 Everard of Ypres, Dialogus Ratii et Everardi, ed. Häring, 252: „Cui Carnoti quartus in lectionem, Parisius in aula episcopi fere tercentesimus assedi.«

50 Thierry of Chartres, Commentaries on Boethius; Gilbert of Poitiers, Commentaries on Boethius.

51 John of Salisbury, Historia Pontificalis, 13, ed. Chibnall, 28-38. 
(2) The Professionalization of Theology and Its Critics: 1150-1200

The deaths of Bernard of Clairvaux in 1153 and Gilbert of Poitiers the following year brought an end to a period of intellectual thought dominated by the clash of a few strong personalities, evident in the heresy trials of Abelard at Sens in 1141 and of Gilbert at Reims in 1148. This did not mean, however, that there was any lessening in the vigour of debate between rival competitive schools. A few Augustinian canons, like Gerhoh of Reichersberg, John of Cornwall, and Walter of Saint-Victor, tended to take over the role of polemicizing against scholastic excess. ${ }^{22}$ It would be quite misleading, however, to assume that they represented "monastic theologians «, critical of scholastic theologians in general. Rather, these critics were responding to increasing professionalization in the teaching of a discipline in which there was great diversity of approach.

There was no clear agreement about how teaching should be organized. One of the earliest syntheses (perhaps from the 1140s) was the Summa sententiarum, organized into seven relatively concise sections, about discussion of faith in God as a Trinity of persons and as the incarnate Word, the creation of the angels and man, and the various sacraments, concluding with marriage. The fact that there is no certainty about its authorship (assigned variously to Walter of Mortagne or Otto of Lucca) reflects its character as a summary of views rather than as a distinct voice in the classroom..$^{53}$ While, in many of its sections, it criticizes views held by Abelard (such as that God could not act other than as he did), there are occasional passages where a distinct position of his (such as the definition of caritas as amor honestus directed to its appropriate end) is repeated. ${ }^{54}$ This reflects the potential capacity of scholasticism to absorb a wide range of opinions. This willingness to embrace views of Abelard is not widespread, however. It does not occur in the eight parts of the Sententie of Robert Pullen (c. 1080-1144), a prolix treatise that does not incorporate any significant philosophical discussion into the study of Christian teaching other than an opening allusion to Aristotle's teaching that everything was either substance or accident. ${ }^{55}$

By contrast, Robert of Melun, who taught both dialectic and theology in Paris between the 1130 s and 1160, when he returned to England, was much more open to applying his interest in semantic theory to explaining Christian doctrine. He did so in such an extended manner, however, that he never lived to complete the book on the Sentences on which he embarked after completing his commentary on the Pauline Epistles. In its prologue, Robert defends his method as a conscious attempt to bring together the method of two great teachers, both of whom he says he has listened to in person - one (Hugh of Saint-Victor) who focused on sacraments, the other (certainly Peter Abelard) on faith and love. He does so while polemicizing against "masters of the glosses " who can quote glosses on scripture with the greatest of ease, but do not understand their import: "For there the text is pruned, the gloss is worshipped with devout veneration, the text is read for the gloss, and the gloss not explained for the sake of the text. $^{56}$ Robert's lament, presumably formulated in the late 1150 s or early 1160 ,

\footnotetext{
52 John of Cornwall, Eulogium, ed. Häring; Gerhoh of Reichersberg, Letter, ed. Häring; Walter of Saint-Victor, Contra quatuor labyrinthos Franciae.

53 Colish, Otto of Lucca.

54 Summa sententiarum 7.8, col. 126A.

55 Robert Pullen, Sententiarum 1: 1, col. 675A.

56 Robert of Melun, Sententie, Prol., ed. Martin 1: 10-12.
}

medieval worlds $\bullet$ No. $12 \cdot 2020 \cdot 12-32$ 
touches on a profound shift that was taking place in the Parisian schools. It was provoked by a rapid growth in student numbers and marked by the disappearance of charismatic teachers such as Abelard and Hugh, whose reputation was related more to their personality and commanding presence than to their capacity to provide useful textbooks. The figure who was most influential in promoting study of the Glossa ordinaria, a standardized set of glosses on scripture initially developed by Anselm of Laon and his immediate disciples, was Peter Lombard, whose reputation started to develop in the early 1140s, but who would become for a short while bishop of Paris (1159-1160).$^{57}$ Lombard's glosses on the Psalms and the Pauline Epistles, composed during the 1140s, would lay the ground for his Four Books of Sentences. Unlike Hugh of Saint-Victor, he shows no particular interest in learning from Jewish perspectives on the Hebrew Bible.

Peter Lombard also benefited from having access to Gratian's Decretum, initially completed in Bologna c. 1140 as the first great overview of canon law since the time of Ivo of Chartres (c. 1040-1115). Although his focus was on canon law rather than speculative theology, Gratian's analysis (which drew on Abelard's Sic et non as well as Ivo's Decretum) deserves to be seen as presenting a theological exposition of penance and the sacraments. ${ }^{58}$ Lombard was aware of the ambitious attempts of both Peter Abelard and Gilbert of Poitiers to reformulate Christian teaching in terms of their attempts to integrate Aristotelian understanding of language or a Platonic awareness of the forms underpinning creation. Peter Lombard's technique, central to his success, was to eschew explicit philosophical discussion in expounding doctrine, focusing instead on the classic Augustinian teaching that all teaching is about signs or things. While he certainly studied Abelard's Theologia "Scholarium « for its discussion of patristic texts, he consciously disagreed with many of Abelard's teachings, such as about the attributes of the three persons, or his argument that God could act only in the way that he did..$^{59}$ In this respect, Peter Lombard was fully aware of Bernard's criticisms of Abelard, formulated at the Council of Sens in 1141, but sought to address them by rational discussion of key patristic texts rather than by polemic.

Not everyone agreed with the way Peter Lombard examined particular doctrines, in particular that of Christology. In the two decades after his death, a range of controversialists raised to respect the traditions of Saint-Victor were cautious about the way he discussed Christology in his Sentences. ${ }^{60}$ They claimed that he identified Christus as a term rather than an actual thing (res). In 1170, Gerhoh of Reichersberg was one of a group of Augustinian canons who succeeded in getting Pope Alexander III to issue an edict condemning the Christology attributed to Peter Lombard. Their fear was that Peter Lombard's discussion of different views of Christ's identity was challenging Catholic orthodoxy. This polemic served to stoke controversy between two scholarly networks, one shaped by those who studied at the cathedral school of Notre-Dame (where the Lombard had many admirers), the other more influenced by the traditions of Richard of Saint-Victor (d. 1173), see below.

57 Besides Colish, Peter Lombard, see also Rosemann, Peter Lombard.

58 Wei, Gratian the Theologian, 297-301.

59 On Peter Lombard's citations of patristic texts from Abelard's Theologia »Scholarium«, see the introduction to the critical edition, CCCM 13: 264-266.

60 Monagle, Orthodoxy and Controversy. 
Luisa Valente has drawn attention to the intriguing diversity of attitudes to language in theological writings from the later twelfth century. Thus she shows that while Peter Lombard avoided extensive discussion of semantic issues, Robert of Melun, a trained dialectician, gave much attention in his theological Sententie to discussing how words could change their meaning in different contexts, notably when they were applied to God. By contrast, Peter of Poitiers (c. 1130-1205), more loyal to Peter Lombard, tends to describe words like iustus and bonus as properly applied to God, without any discussion of the potential fluidity of their meaning. ${ }^{61}$ Prepositinus of Cremona (c. 1140/1150-1210), who studied under Peter Comestor (d. 1178), shows much greater familiarity with contemporary debates about the meaning of words, while remaining loyal to the broad doctrinal assumptions of Peter Lombard. ${ }^{62}$ As chancellor of Notre-Dame 1168-1178, Comestor played a key role in promoting the memory and exegetical method of Peter Lombard (d. 1160) within the exegetical schools. His background was more in scripture than the study of language. Nonetheless, Comestor's Historia scholastica - a synthesis of biblical history of enormous influence - can be seen, as Mark Clark has argued, as seeking to combine Peter Lombard's interest in debating doctrine with Hugh of Saint-Victor's interest in scripture as the foundation on which all theology rests. ${ }^{63}$ Peter Lombard's Sentences had the great virtue of providing a solid framework into which discussion of both scripture and dialectic could be integrated.

There were other perspectives, however, that could frame discussion of Christian doctrine. The most important of these was that of the Porretani, admirers of Gilbert of Poitiers, whose identity is difficult to discern because Porretan texts, such as Invisibilia Dei and the Summa Zwettlensis, are frequently anonymous and not widely diffused in manuscript. Their distinguishing feature is that their teachings about the theory of language, in particular about the theory of translatio, how words could change their meaning when applied to God, were closely related to those about theology. Perhaps the most brilliant personality associated with this school was Alan of Lille (c. 1125/1130-1203), a figure much influenced by Gilbert of Poitiers. We know little about his career other than that he spent time in the south, most likely at Montpellier in the 1180 s. ${ }^{64}$ He probably taught for a good deal of his career at Paris, before deciding to end his life as a Cistercian monk. His Summa "Quoniam homines", dated variously to 1160 or 1180 , opens with extravagant rhetoric about the liberal arts serving "as a bridge to the imperial domain of the theological faculty « and thus bringing an end to heresy. ${ }^{65} \mathrm{He}$ drew on the commentary of Scotus Eriugena on Dionysius the Areopagite to explain that theologia was both supercelestial (on the divine nature) and subcelestial (on the realm of creation), beyond the domain of natural philosophy ${ }^{66}$ Its specialized terminology meant that it would never reach a wide audience. By contrast, his Regulae caelestis iuris formulated an

61 Valente, Logique et théologie, 28, 179-183.

62 Valente, Logique et théologie, 29, 235-257.

63 Clark, Historia scholastica, 23-43.

64 On Alan's career, see d'Alverny, Textes inédits, 26-27 and Pearson, Text and Situation, 47-52.

65 Alan of Lille, Summa Quoniam homines, Prol. 1, ed. Häring, 119: „Cumque liberalium artium ponte introductorio in imperialem theologice facultatis regiam intruduntur, in varias hereses et in varia hereseos precipicia detrusi naufragantur.«

66 Ibid. 1.2, ed. Häring, 121. 
axiomatic method for theological reflection that was more widely copied, including within Cistercian houses. Alan's emphasis on the capacity of words to change their meaning when applied improprie to God was very different from that of Peter Lombard and his followers. The sustained criticisms of such arguments about language made by Prepositinus of Cremona indirectly reveal that Alan of Lille and his admirers played a significant role in offering an alternative perspective on theological language within the Parisian schools in the later twelfth century.

Alan did not confine his teaching to purely abstract, philosophical matters. During his time at Montpellier (c. 1185), he composed his De fide catholica contra haereticos, dedicated to William VIII, count of Montpellier (1172-1202), in four books, each directed against the arguments of a specific group: Cathars, Waldensians, Jews and Muslims ${ }^{67}$ Whereas Roscelin and Anselm in the late eleventh century had referred only vaguely to arguments put by Jews and pagani, Alan extended what he found in Gilbert Crispin's dialogue, becoming more precise in his presentation of contemporary critiques of Catholic doctrine, and the need for them to be countered by reason as well as authority. His portrayal of specific arguments of each of these groups shows that he sought to restructure the conventional presentation of Christian doctrine becoming standard in the Parisian schools in a way that was more aware of the situation outside a scholastic milieu. In the case of pagani seu Mahometani, Alan counters what he claims to be their teachings about Jesus as not having suffered on the cross, material refreshment in Paradise, marriage, and images. ${ }^{68}$ Such anti-heretical writing effectively extended theological debate to a wider community than that of the Parisian schools.

Another type of criticism of the type of theology being pursued by disciples of Peter Lombard was that developed by Richard of Saint-Victor (d. 1173), who extended the teaching style of Hugh of Saint-Victor into a more mystical direction, but never developed any overview of Christian doctrine on the pattern of the De sacramentis. Andrew of Saint-Victor (d. 1175), who served as its prior in the 1140 s before transferring to a new foundation at Wigmore, England, was committed to extending Hugh's interest in the historical dimension of the Hebrew scriptures. He did not apply himself, however, to doctrinal issues. Richard, prior at Saint-Victor from 1162 until his death, gave much more emphasis to its allegorical and moral dimensions, with a particular focus on the ascent and transformation of the soul. Richard was certainly familiar with the writings of St Anselm, never cited by Peter Lombard, and emulated his path of pursuing arguments from reason alone. After Hugh's death in 1141, no single perspective emerged at the abbey although the public school at Saint-Victor seems to have disappeared. In consequence, Saint-Victor functioned much more as a community with canons holding a wide range of perspectives, rather than pursuing a single school of thought.

67 Alan, De fide, cols. 305-428; on this text, see Häring, De fide catholica, and D'Alverny, Alain de Lille et 1'Islam. 68 Alan, De fide, cols. 421-428. 
Richard of Saint-Victor's De trinitate addresses the same doctrinal question as had confronted Roscelin in the late eleventh century, namely how to explain how an undivided God could also be three distinct persons. Richard's response was to re-assert Abelard's account of the three divine attributes, but doing so by reason alone, with hardly any explicit reference to philosophical or patristic authority. ${ }^{69}$ Unlike Peter Lombard, he opened his account of the Trinity by reflecting on how the mind rises in awareness through experience, ratiocination and belief. ${ }^{70}$ Underpinning his analysis is a much more dynamic sense of the Trinity than emerges in the first book of the Sentences. A favourite concept is that of the fullness (plenitudo) of each of the divine attributes, all leading to the fullness of supreme love, both as caritas and amor. Richard's argument proceeds by way of question and answer, but always referring back to the notion that the divine attributes are known by experience (experimenta and experientia). He refrains from debating other perspectives until a passage in the sixth book in which he laments those contemporaries (presumably including Peter Lombard) who deny that one divine substance can generate another substance on the grounds that there is a single divine substance.$^{71}$ Richard distrusted any theology that seemed to undermine respect for the fullness of divinity in each of the three persons.

Even within the abbey of Saint-Victor, there was no single attitude to other scholastics. Richard's subprior, Walter of Saint-Victor (d. c. 1180) wrote a sustained invective, Against the Four Labyrinths of France, in which he attacked Peter Abelard, Gilbert of Poitiers, Peter Lombard, and Peter of Poitiers. By contrast, another canon in the community, Godfrey of Saint-Victor (c. 1125-1195), formulated a much more open attitude to philosophical learning and its relationship to spiritual wisdom in his Fons philosophiae, a text that is in many ways closer to the humanism of Alan of Lille. ${ }^{72}$ The diversity of perspectives held by different teachers at Saint-Victor reflects the diversity of attitudes to pursuing theological enquiry within the Parisian schools more generally. The abbey provided a space for a range of alternatives to what was increasingly becoming perceived as the post-Lombardian mainstream at the cathedral of Notre-Dame. Its former students were rapidly gaining power in the echelons of the Church.

Peter Lombard's Sentences started to become widely accepted as normative after the Third Lateran Council of 1179, where, despite pressure from polemicists like John of Cornwall, no official censure was made of his teaching. ${ }^{73}$ Copies continued to circulate in libraries of both monks and canon regulars. Not all monks, however, were aligned to its perspectives. Joachim of Fiore (1135-1202), a former lawyer in the court of Palermo who sought, in the late 1160 s, to establish a monastic foundation initially at the Cistercian abbey of Corazzo, developed a very different way of resolving how the three persons might co-exist in one God. ${ }^{74}$ His method, however, was not through Anselm's technique of arguing through reason alone, but

69 There is a single reference to Augustine in Richard of Saint-Victor, De trinitate 4.20, ed. Ribaillier, 186.

70 Richard of Saint-Victor, De trinitate 1.1, ed. Ribaillier, 86.

71 Richard of Saint-Victor, De trinitate 6.22, ed. Ribaillier, 259. Godfrey of Saint-Victor, Fons philosophiae.

Châtillon, Lateran III, 83-88.

Studies of Joachim tend to consider his reading of scripture as very different from that of scholastic exegetes. See Potestà, Tempo dell'Apocalisse; on Joachim's criticism of Peter Lombard, there has been extensive literature, often (though not always) building on themes of the hostility of monasticism and scholasticism, as in McGinn, Abbot and the doctors. See also Lerner, Joachim and the scholastics, and Daniel, Heresy and Abbot Joachim. 
through close study of the Old and New Testaments, interpreted, not allegorically, but as a record of the operation of the Father, Son, and Holy Spirit in history. Joachim's community had no access to or interest in the discussions of language and philosophy that prevailed in Paris. Instead, Joachim drew their attention to scripture as a record of the continually unfolding nature of God's self-revelation both to the Jewish people and, through the Holy Spirit, to all humanity. His sense of the historical foundation of scripture owes much to Hugh of Saint-Victor. Joachim would certainly have encountered Hugh's writings at the Cistercian abbey of Casamari, where he stayed from 1182-1184. It was physically adjacent to the papal residence at Vereoli, from where Pope Alexander III issued his edict against Peter Lombard's Christology in 1170. It is quite possible that Joachim encountered echoes of this polemic at Casamari. Whether or not he came across the concluding polemic in Richard of Saint-Victor's De trinitate against certain unnamed masters, Joachim's way of presenting the Trinity was radically different from that of Peter Lombard in being visual rather than conceptual. ${ }^{75}$ To explain the Trinity he invoked the image of a psaltery, in which the equal stature of the divine persons was made manifest by its three major corners, which enclosed a circle, symbol of eternity. This self-revelation came to humanity in stages, first through the Father, and only subsequently through the Son and Holy Spirit. ${ }^{76}$ To separate the persons from their collective substance was perfidy. When he repeated this complaint in his Commentary on the Rule of Benedict, he identified Peter Lombard as guilty of this heresy. Joachim was here presenting himself as successor to Bernard of Clairvaux as a defender of orthodoxy ${ }^{77}$ His way of reading scripture, however, as a manifestation of the Holy Spirit to the apostolic community, was very different from that of Bernard of Clairvaux, who focused much more on God's Word as visiting the soul. The communities they inspired formulated very different ways of interpreting both scripture and the doctrine of the Trinity.

While Joachim was certainly misreading Peter Lombard's argument, he was consciously imitating the technique of polemicizing against unspiritual schoolmen, such as pursued by Bernard of Clairvaux against Abelard, to consolidate his own identity as a theologian and prophet absorbed by the distinct ways in which God the Father, Son, and Holy Spirit, manifested themselves in history. Joachim, who never left southern Italy, apart from going on pilgrimage to the Holy Land before deciding to enter monastic life, used the image of Peter Lombard as an unspiritual scholastic to promote an interpretation of scripture that he considered to be more relevant to his own community than anything coming out of the Parisian schools. Peter Lombard's authority was only fully affirmed in 1215, when Pope Innocent III took the unparalleled step of promoting the orthodoxy of Peter Lombard, against what he saw as the unjustified criticisms made of Lombard's trinitarian theology by Joachim of Fiore (d. 1202). ${ }^{78}$

On the possibility of Joachim encountering Richard, see Mews and Monagle, Fourth Lateran Council. Yee contrasts Richard's approach to the exegetical foundations of Joachim's Trinitarian theology in "Plenitudo intelligentiarum«, 85-86.

76 Joachim of Fiore, Psalterium decem chordarum 1.5, ed. Selge, 77.

77 Joachim of Fiore, Psalterium decem chordarum 1.1, ed. Selge, 20; Joachim of Fiore, Tractatus in Expositionem vite et regule beati Benedicti 3.2, ed. Patchovsky, 208-209.

78 Concilium Lateranense, 2, in Conciliorum, ed. Alberigo et al., 231. 


\section{Conclusion}

The dynamism of scholastic debate in the twelfth century was generated by intense competition between a range of communities, involving a wide range of monks, regular canons, and secular clergy. To define these debates simply in terms of antagonism between monastic and scholastic currents of thought does not do justice to their complexity. The declaration of Pope Innocent III in favour of Peter Lombard against the criticisms voiced by Joachim of Fiore might seem, on the surface, to epitomize a transition between monastic and scholastic currents of thought, reversing the situation that had prevailed in the late eleventh century, when Anselm of Bec argued against Roscelin of Compiègne. Yet when we explore these various confrontations in more detail, it is evident that even within monastic communities there was great diversity of opinion about how best to interpret the scriptures and formulate doctrine. Rather than speak about monastic theology, as such, it may be more helpful to identify the experiential dimension that certain monks, particularly (but not exclusively) within the Cistercian Order, sought to develop. This was also a perspective that became important at the abbey of Saint-Victor, although not necessarily in an anti-scholastic manner. Bernard of Clairvaux may have disliked the theological claims of Peter Abelard, but this was not a distinctively monastic perspective. He was simply voicing the opinion of many schoolmen, who disliked the willingness of Abelard to criticize established authority.

Not many theologians in the twelfth century repeated the argument made by Roscelin of Compiègne that Latin Christians needed to defend their faith in the same way as Jews and Muslims sought to defend their religious traditions. In practice, they were largely ignorant of the prolific flowering of debate that was taking place within a range of communities, Jewish and Muslim, across the Mediterranean world and beyond. They were more preoccupied by the problem of diverse interpretation within Christian tradition than by the challenge of how to co-exist with other religious traditions. Yet a significant number of those twelfth century masters and their communities were aware that they had much to learn from voices from outside Latin Christendom. There was no agreement on how these voices should be put together. We may be much better placed in the twenty-first century to appreciate the parallels as well as contrasts between those various communities. The particular value of studying scholasticism in twelfth century Europe is that we can see the diversity of ways which different communities developed to question the intellectual and religious traditions that they inherited. Rather than look at scholasticism in terms of a stable synthesis embodied in the vision of its greatest exponents, it may be more helpful to look at its internal diversity as its most distinctive feature. This, in turn, may help us to the further task of situating Latin scholasticism within the wider context of the educational structures of otherwise very different religious traditions. 


\title{
References
}

\author{
Abbreviations \\ BGPMA = Beiträge zur Geschichte der Philosophie des Mittelalters \\ CCCM = Corpus Christianorum Continuatio Mediaevalis \\ CCSL $=$ Corpus Christianorum Series Latina \\ $\mathrm{PL}=$ Patrologiae Cursus Completus, Series Latina
}

\section{Primary Sources}

Alan of Lille, De fide catholica contra haereticos, PL 210, cols. 305-428.

Anselm of Canterbury, Anselmi Opera Omnia, 6 vols. (Edinburgh, 1938-1961).

Anselm of Laon, Glossae super Iohannem, ed. Alexander Andrée, CCCM 267 (Turnhout, 2014). Augustine, De civitate Dei, ed. B. Dombart and A. Kalb, CCSL 47-48 (Turnhout, 1955).

Bernard of Clairvaux, Sancti Bernardi Opera, ed. Jean Leclercq, C. H. Talbot and Henri Rochais, 8 vols. (Rome, 1957-1977).

Chartularium Universitatis Parisiensis, ed. H. Denifle and E. Châtelain, 4 vols. (Paris, 18891897).

Codex Udalrici, ed. P. Jaffé, Bibliotheca rerum germanicarum 5 (Berlin, 1969).

Conciliorum Oecumenicorum Decreta, ed. J. Alberigo, J. A. Dossetti, P. P. Joannou, C. Leonardi and P. Prodi (Bologna, 1973).

Corpus chronicorum Bononiensium, ed. Albano Sorbelli, Rerum Italicarum Scriptores: Raccolti degli Storici Italiani 18, 4 parts (Città di Castello, 1910-1939).

Everard of Ypres, Dialogus Ratii et Euerari, ed. Nikolaus M. Häring, A Latin Dialogue on the Doctrine of Gilbert of Poitiers, Mediaeval Studies 15 (1953) 245-289.

Gerhoh of Reichersberg, Letter to Pope Hadrian about the Novelties of his Day, ed. Nikolaus M. Häring (Toronto, 1974).

Gilbert of Poitiers, The Commentaries on Boethius of Gilbert of Poitiers, ed. Nikolaus M. Häring (Toronto, 1966).

Guibert of Nogent, Autobiographie, ed. Edmond-René Labande (Paris, 1981).

Hugh of Saint-Victor, De scripturis et scriptoribus sacris praenotatiunculae, PL 175, cols. 9-28.

Hugh of Saint-Victor, Didascalicon De Studio Legendi, ed. C. H. Buttimer (Washington, DC, 1939).

Hugh of Saint-Victor, Super Hierarchiam Dionysii, ed. D. Poirel, CCCM 178 (Turnhout, 2015). Joachim of Fiore, Psalterium decem chordarum, ed. Kurt-Victor Selge (Rome, 2009).

Joachim of Fiore, Tractatus in Expositionem vite et regule beati Benedicti, ed. Alexander Patchovsky (Rome, 2008).

John of Cornwall, Eulogium, ed. Nikolaus M. Häring, The Eulogium ad Alexandrum Papam tertium of John of Cornwall, Mediaeval Studies 13 (1951) 253-300.

John of Salisbury, Historia pontificalis, ed. and trans. Marjorie Chibnall (Oxford, 1986).

John of Salisbury, Metalogicon, ed. J. B. Hall, CCCM 98 (Turnhout, 1991).

Peter Abelard, The Letter Collection of Peter Abelard and Heloise, ed. David E. Luscombe, trans. B. Radice (Oxford, 2013).

Peter Abelard, Problemata Heloissae, PL 178, cols. 677-730.

Peter Abelard, Theologia "Scholarium «, ed. E.-M. Buytaert and C. J. Mews, Petri Abaelardi Opera Theologica 3, CCCM 13 (Turnhout, 1987) 203-549.

Peter Lombard, Sententiae in IV libris distinctae, ed. Ignatius Brady, 3 vols. (Grottaferrata, 1971-1981). 
Richard of Saint-Victor, De trinitate, ed. Jean Ribaillier (Paris, 1958).

Robert Pullen, Sententiarum libri octo, PL 186, cols. 639-1010.

Roscelin, Epistola ad Petrum Abaelardum, ed. J. Reiners, Der Nominalismus in der Frühscholastik: Ein Beitrag zur Geschichte der Universalienfrage im Mittelalter. Neben einer neuen Textausgabe des Briefes Roscelins an Abaelard, BGPMA 8 (Münster, 1910) 63-80.

Sententie Parisienses, ed. Arthur Landgraf, Ecrits théologiques de l'école d'Abélard (Louvain, 1934) 3-60.

Stephen Harding, Censura de aliquot locis Bibliorum, PL 166, cols. 1373D-1376A.

Summa sententiarum, PL 176, cols. 41-173.

Thierry of Chartres, Commentaries on Boethius by Thierry of Chartres and his School, ed. Nikolaus M. Häring (Toronto, 1971).

Walter of Saint-Victor, Contra quatuor labyrinthos Franciae, ed. Palémon Glorieux, Archives d'histoire doctrinale et litéraire du moyen âge 19 (1952) 185-335.

\section{Secondary Sources}

Agus, Irving, Urban Civilization in Pre-Crusade Europe: A Study of Organized Town-Life in North-Western Europe during the Tenth and Eleventh Centuries Based on the Responsa Literature, 2 vols. (Leiden, 1965).

Andrée, Alexander, Anselm of Laon unveiled: The Glosae super Iohannem and the origins of the Glossa ordinaria on the Bible, Mediaeval Studies 73 (2011) 217-260.

Bautier, Robert-Henri, Paris au temps d'Abélard, in: Jean Jolivet (ed.), Abélard en son temps (Paris, 1981) 21-77.

Brezik, Victor B. (ed.), One Hundred Years of Thomism: Aeterni Patris and Afterwards, a Symposium (Houston, Texas, 1981).

Chadwick, Henry, Symbol and reality: Berengar and the appeal to the fathers, in: Peter Ganz, R. B. C. Huygens and Friedrich Niewöhner (eds.), Auctoritas und Ratio: Studien zu Berengar von Tours (Wiesbaden, 1990) 25-46.

Châtillon, Jean, Lateran III et l'enseignement Christologique de Pierre Lombard, in: Jean Longère (ed.), Le troisième concile de Latran (1179) (Paris, 1982) 75-90.

Clark, Mark J., The Making of the Historia scholastica, 1150-120o (Toronto, 2015).

Cohen, Mordechai A., A new perspective on Rashi of Troyes in light of Bruno the Carthusian: Exploring Jewish and Christian Bible interpretation in eleventh-century northern France, Viator 48/1 (2017) 39-86.

Colish, Marcia, Authority and interpretation in scholastic theology, in: Judith Frishman, Willemien Otten and Gerard Rouwhors (eds.), Religious Identity and the Problem of Historical Foundation: The Foundational Character of Authoritative Sources in the History of Christianity and Judaism (Leiden, 2004) 369-386.

Colish, Marcia, Otto of Lucca, author of the Summa sententiarum? in: C. J. Chandler and S. A. Sofferahn (eds.), Discovery and Distinction in the Early Middle Ages: Studies in Honor of John J. Contreni (Kalamazoo, MI, 2013) 57-72.

Colish, Marcia, Peter Lombard, 2 vols. (Leiden, 1994).

Colish, Marcia, Remapping Scholasticism, The Etienne Gilson Series 21 (Toronto, 2000) 1-21.

Colish, Marcia, St. Thomas Aquinas in historical perspective: The modern period, Church History 44/4 (1975) 433-449.

Colish, Marcia, Studies in Scholasticism (Aldershot, 2006).

Colish, Marcia, Systematic theology and theological renewal in the twelfth century, Journal of Medieval and Renaissance Studies 18 (1988) 135-156. 
Cowdrey, Herbert E. J., Lanfranc: Scholar, Monk and Archbishop (Oxford, 2003).

Daniel, E. Randolph, Heresy and Abbot Joachim of Fiore, in: Abbot Joachim of Fiore and Joachimism, Variorum Collected Studies Series, 1985 (Aldershot, 2011).

D’Alverny, Marie-Thérèse, Alain de Lille et 1'Islam: Le "Contra Paganos«, in: Islam et chrétiens du Midi (Toulouse, 1983) 301-350.

D’Alverny, Marie-Thérèse, Alain de Lille: Textes inédits (Paris, 1965).

D'Onofrio, Giulio, History of Theology 2: The Middle Ages, trans. Matthew J. O'Connell (Collegeville, Minn., 2008).

Gangl, Peter, Franz Ehrle (1845-1934) und die Erneuerung der Scholastik nach der Enzyklika Aeterni patris (Regensburg, 2006).

Gastaldelli, Teologia monastica, teologia scolastica e lectio divina, Analecta Cisterciensia 46 (1990) 25-63.

Ghellinck, Joseph de, Le mouvement théologique du XIIe siècle: Sa préparation lointaine avant et autour de Pierre Lombard, ses rapports avec les initiatives des canonistes, études, recherches et documents (second edition) (Bruges, 1948).

Giacone, Roberto, Masters, books and library at Chartres, according to the cartularies of Notre-Dame and Saint-Père, Vivarium 12 (1974) 30-51.

Gilbert Crispin, Disputatio Iudei et Christiani, in: Anna S. Abulafia and Gillian R. Evans (eds.), The Works of Gilbert Crispin, Abbot of Westminster (London, 2004) 1-53.

Giraud, Cédric, Per verba magistri: Anselme de Laon et son école au XIIe siècle (Turnhout, 2010).

Giraud, Cédric and Constant J. Mews, John of Salisbury and the schools of the twelfth century, in: Christophe Grellard and Frédérique Lachaud (eds.), A Companion to John of Salisbury (Leiden, 2015) 31-62.

Godfrey of Saint-Victor, Fons philosophiae, ed. P. Michaud-Quentin (Namur, 1956).

Grabmann, Martin, Die Geschichte der scholastischen Methode nach den gedruckten und ungedruckten Quellen bearbeitet, 2 vols. (Freiburg im Breisgau, 1909-1911).

Grossman, Avraham, The school of literal exegesis in northern France, in: S. Magne (ed.), Hebrew Bible/Old Testament: The History of its Interpretation. Vol. 1: From the Beginnings to the Middle Ages (Göttingen, 2000) 326-331.

Häring, Nikolaus M., Alan of Lille's De fide catholica or Contra haereticos, Analecta Cisterciensia 32 (1976) 216-237.

Landgraf, Artur, Introduction à l'histoire de la littérature théologique de la scolastique naissante, ed. Albert-M. Landry (Montreal, 1973).

Leclercq, Jean, The Love of Learning and the Desire for God: A Study of Monastic Culture, trans. Catherine Misrahi (New York, 1961).

Leinsle, Ulrich G., Introduction to Scholastic Theology, trans. Michael Miller (Washington DC, 2010)

Lerner, Robert E., Joachim and the scholastics, in: R. Rusconi (ed.), Gioacchino da Fiore tra Bernardo di Clairvaux e Innocenzo III, Atti del $5^{\circ}$ Congresso internazionale di studi gioachimiti (San Giovanni in Fiore, 16-21 settembre 1999), Opere di Gioacchino da Fiore: Testi e strumenti 13 (Rome, 2001) 251-264.

Madigan, Daniel A., The search for Islam's true scholasticism, in: José Cabezón (ed.), Scholasticism and Cross-Cultural Perspectives (Albany, NY, 1998) 35-64.

Makdisi, George, The Rise of Colleges: Institutions of Learning in Islam and the West (Edinburgh, 1981). 
Makdisi, George, The Rise of Humanism in Classical Islam and the Christian West, With Special Reference to Scholasticism (Edinburgh, 1990).

Makdisi, George, Scholasticism and humanism in classical Islam and the Christian West, Journal of the American Oriental Society 109 (1989) 175-182.

Makdisi, George, The Scholastic method in medieval education: An inquiry into its origins in law and theology, Speculum 49/4 (1974) 640-661.

McGinn, Bernard, The Abbot and the doctors: Scholastic reactions to the radical eschatology of Joachim of Fiore, Church History 40 (1971) 30-47.

Mews, Constant J., Bruno of Rheims and Roscelin of Compiègne on the Psalms, in: Michael W. Herren, Christopher J. McDonough and Ross G. Arthur (eds.), Latin Culture in the Eleventh Century: Proceedings of the Third International Conference on Medieval Latin Studies Cambridge, 9-12 September 19982 (Turnhout, 2002) 129-152.

Mews, Constant J., Bruno of Reims and the evolution of scholastic culture in northern France 1050-1100, in: Hartmut Beyer, Gabriela Signori and Sita Steckel (eds.), Bruno the Carthusian († 1101) and his Mortuary Roll: Studies, Text, and Translation, Europa Sacra 16 (Turnhout, 2014) 49-81.

Mews, Constant J., Communities of learning: Schools and colleges in Paris in the 13th century, in: Constant J. Mews and John N. Crossley (eds.), Communities of Learning: Networks and the Shaping of Intellectual Identity in Europe 1100-1500 (Turnhout, 2011) 109-135.

Mews, Constant J., The Council of Sens (1141): Abelard, Bernard, and the fear of social upheaval, Speculum 77/2 (2002) 342-382.

Mews, Constant J., Scholastic theology in a monastic milieu in the twelfth century: The case of Admont, in: Alison Beach (ed.), Manuscripts and Monastic Culture: Religious Reform and Intellectual Life in Twelfth-Century Germany (Turnhout, 2007) 217-239.

Mews, Constant J., St Anselm, Roscelin and the see of Beauvais, in: David E. Luscombe and Gillian R. Evans (eds.), Anselm: Aosta, Bec and Canterbury (Sheffield, 1996) 106-119.

Mews, Constant J., William of Champeaux, the foundation of St Victor (Easter 1111) and the chronology of Abelard's early career, in: I. Rosier-Catach (ed.), Arts du langage et théologie aux confins des XIe et XIIe siècle (Turnhout, 2011) 83-104.

Mews, Constant J. and Clare Monagle, Peter Lombard, Joachim of Fiore and the Fourth Lateran Council, Medioevo: Rivista di storia della filosofia medievale 35 (2010) 81-122.

Mews, Constant J. and Micha Perry, Peter Abelard, Heloise, and Jewish biblical exegesis in the twelfth century, Journal of Ecclesiastical History 61 (2011) 3-19.

Monagle, Clare, Orthodoxy and Controversy in Twelfth-Century Religious Discourse: Peter Lombard's »Sentences" and the Development of Theology (Turnhout, 2013).

Moore, Rebecca, Jews and Christians in the Life and Thought of Hugh of St. Victor (Atlanta, 1998).

Pearson, Joseph H., The Text and Situation of Alan of Lille's De fide catholica: The Prologue and Book III, "Contra Iudeos". Unpublished PhD thesis (University of Notre Dame, 2001).

Pieper, Josef, Scholasticism: Personalities and Problems of Medieval Philosophy, trans. Richard and Clara Winston (London, 1961).

Poirel, Dominique, Tene fontem et totum habes: l'Unité du Didascalicon de Hugues de Saint-Victor, in: Cedric Giraud and Martin Morard (eds.), Universitas scolarium: Mélanges offerts à Jacques Verger (Geneva, 2011) 293-328.

Potestà, Gian-Luca, Il tempo dell'Apocalisse: Vita di Gioacchino da Fiore (Rome, 2004).

Quinto, Riccardo, Scholastica: Storia di un concetto (Padua, 2001).

Rosemann, Philipp, Peter Lombard (Oxford, 2004). 
Smith, Lesley, The Glossa ordinaria: The Making of a Medieval Bible Commentary (Leiden, 2009).

Southern, Richard W., Humanism and the school of Chartres, in: Richard William Southern (ed.), Medieval Humanism and Other Studies (Oxford, 1970) 61-85.

Steckel, Sita, Networks of learning in Byzantine east and Latin west: Methodological considerations and starting points for further work, in: Sita Steckel, Niels Gaul and Michael Grünbart (eds.), Networks of Learning: Perspectives on Scholars in Byzantine East and Latin West (Berlin, 2015) 185-234.

Valente, Luisa, Logique et théologie: Les école parisennes entre 1150 et 1220 (Paris, 2008).

Van Liere, Frans A., Andrew of St. Victor, Jerome, and the Jews: Biblical scholarship in the twelfth-century renaissance, in: Thomas J. Heffernan and Thomas E. Burman (eds.), Scripture and Pluralism: Reading the Bible in the Religiously Plural Worlds of the Middle Ages and Renaissance (Leiden, 2005) 59-75.

Ventresca, Robert A., "A plague of perverse opinions«: Leo XIII's Aeterni patris and the Catholic encounter with modernity, Logos: A Journal of Catholic Thought and Culture 12/1 (2008) 143-168.

Wei, Ian P., From twelfth-century schools to thirteenth-century universities: The disappearance of biographical and autobiographical representations of scholars, Speculum 86 (2011) 42-78.

Wei, Ian P., Intellectual Culture in Medieval Paris Theologians and the University, c.110o1330 (Cambridge, 2012).

Wei, John C., Gratian the Theologian (Washington, DC, 2016).

Wilmart, André, Les livres légués par Célestin II à Cittá di Castello, Revue bénédictine 35 (1923) 98-102.

Yee, Ethan Leon, »Plenitudo intelligentiarum«: The implications of the Trinity on Joachim of Fiore's exegesis, Viator 50 (2019) 77-106. 